\title{
Experiential learning and College English Picture Book Intensive Reading Course Teaching
}

\section{Lingling Qin}

\author{
Foreign Languages Department of Yuzhang Normal College
}

Key words: experiential learning, English picture book intensive reading teaching, application

\begin{abstract}
In the teaching of college English picture book intensive reading course, teachers should pay attention to the application of experiential learning method.This paper analyzes the specific strategies of experiential learning in the application of English picture book intensive reading course teaching.Realizing the innovation of education concept and method, to reallyhighlight the dominant position of students in English learning, to stimulate students' intrinsic enthusiasm for English learning and English application, to provide effective support for improving students' English literacy.
\end{abstract}

College English picture book intensive reading course teaching is the basic knowledgeto enrichstudents' language, and is an important way to cultivate students'practical ability in English.In the teaching of college English picture book intensive reading course, exists a problem that the teaching effect is not ideal.A prominent phenomenon is that students spend a lot of time learning intensive reading textbooks, but students' practical English application abilities and communicate and writing abilities are still noteffectively cultivated, still have a lot of students can't speak in English, existsthe phenomenon that students don't understand in English teaching.To change this kind of teaching situation, must innovate the concept and mode of college English picture book intensive reading course teaching, and experiential learning focus on students' individual experience, can highlight the dominant position of students' learning, this way applied in the teaching of college English picture book intensive reading course, will be able to effectively improve the quality and efficiency of the picture book intensive reading classroom teaching.

\section{Understanding of experiential learning}

Experiential learning refers to learners based on past experience, to effectively select, process and deal with the external information, through the way of active experience and active learningto construct the knowledge system.Experiential learning highlights the subjective status of learners, emphasizes the process of learner individual experience and cognition.In experiential learning, teachers attach importance to guide students to autonomous learning and independent experience, attach importance to the cultivation of student's individualized learning ability, attach importance to guide the students' learning initiative and creative consciousness.Experiential learning applied in the process of education practice, learners can give full play to the main body function, on the basis of individual experience and individual practice to explore, learners can effectively learn knowledge and develop ability.Experiential learning is the transcendence of traditional infusion learning mode, highlighting the process of self-construction for knowledge, which is an important choice of education innovation development.

\section{The significance of experiential learning applied in the teaching of college English picture book intensive reading}

Experiential learning applied in the teaching of college English picture book intensive reading course, which can effectively innovate the teaching mode of picture book intensive reading course, and promote the improvement of education effect in picture book intensive reading course teaching.The traditional picture book intensive reading course teaching is a model of knowledge 
explanation mainly based on teachers. In the teaching, neglecting the main role of students, the students passively follow teachers to learn knowledge, learning process is lack of autonomy, and lack of feeling and experience, naturally,students' understanding and cognition of related knowledge are not deep enough, the effect of picture book intensive reading course is not ideal, and students feel that this course is difficult to learn, and produce a greater fear of psychology and boredom in the process of learning. However, experiential learning is the education activity that is carried out by students. In the teaching of English picture book intensive reading course, the application of experiential teaching method can highlight the students' learning subject status.In the specific communicative situation, students constantly experience knowledge and apply the practical application of knowledge, the communicative function of the picture book course can be reflected.In experiential learning, students have more opportunities to experience, associate and apply the English knowledge, students will be more focused in class.In the process of knowledge of English, students will use their brains to solve some problems, the classroom teaching mode changed from simple imparting teaching to experiential teaching, and interactive transformation, teaching effect will be improved significantly.

In experiential learning, students can realize that they are the masters of learning, and students' self-responsibility consciousness can be cultivated.Students will be more aware of their knowledge learning, and can be able to observe and apply knowledge, students' ability to recognize things and learn knowledgecan be greatly improved.In experiential learning, students need to learn autonomously, need to communicate with other students, need to induction and summary the knowledge, students' sense of learning responsibility is trained, study self-consciousness get promoted, students can really become the master of learning.Not only that, there are related activity set in experiential learning, this activity can effectively active classroom atmosphere, can stimulate the enthusiasm of students to explore problems, help to cultivate students' language application ability, help to improve students' English comprehensive literacy ability.

\section{The application of experiential learning in college English picture book course teaching}

\section{(1)Application of experiential learning method in class import link}

In the import design of college English picture book course teaching, teachers need to guide students to apply experiential learning method to study, can activate students' relevant experience, guide the students to combine their own experience to associate and experience, in this process, to learn knowledge and develop English literacy. In the import process, on the one hand, in the design of the import content, teachers need to combine the phenomenonin actual life with students' experience, stimulate the student to associate and experience unceasingly, can guide the student from one point to another, continuously learn new knowledgein the process of import learning.On the other hand, the import content that teacher designed needs to be connected with students' knowledge, to guide students to think and experience, to learn new knowledge and new objective. No matter which way to set up the import, all need to activate the students' related experiences, and guide students to carry out relevant associations and experiences to gain new knowledge.

In the import link, the teachers need to design the import content associated with students' life experience and the knowledge students have learned, can effectively stimulate students' learning desire, so that the students can enter into the learning state as soon as possible.Once students interested in learning, students will keep association and experience in the related links, students will constantly experience the strategy of language application, students will actively find problems and solve problems, to achieve an optimal state of learning, as a result, the import links need to be able to apply experiential learning method.

\section{(2)It is necessary to adopt the experiential learning method in the teaching of new courses}

Teaching new courses is an important part of language input, through teaching new courses mainly enables students to learn and apply new language knowledge, and cultivate students' language application ability.In this link, teachers should be able to guide students to learn through 
experiential learning mode.

In new course teaching, teachers can create a scene for students to use new knowledge to learn and use, create a kind of communication scenarios of language application, through this scenario, motivate and enhance the enthusiasm and creativity of the students' language application, to make the students can fully experience the language and feel the fun of English learning in the process of language application.In this process, the effective interaction between students and students should be realized.Through interactive process, constantly make students learn new knowledge and achieve the purpose of applying language, to create a vivid language application situation.On the one hand, teachers need to study the text deeply and be able to set up problems based on the text key problems and contents in the text that students are interested in.On the other hand, teachers should be able to encourage students to learn from each other and communicate with each other, to highlight the main role of students' learning and communication.

For example, teachers can set up such a question, what are the contents in the text that you are interested in, and let students communicate with each other.Or, depending on your own experience, talk about your understanding of the text and make an appropriate assessment of the author's article.Teachers should set up effective problems, set the students interested in, at the same time, can stimulate the students to associate and image the problems closely linked to students' life experience, through the effective setting of problems, to guide the enthusiasm that the student to discuss and communicate with each other, to make the students constantly apply language knowledge and expand the depth of knowledgein the process of communication experience, toachieve the creative application of language.

\section{(3)Adopting the experiential learning method in the summary of after class}

In the summary of after class can also be used experiential learning method to carry out related activities, through the application of experiential learning, to enable students to better consolidate the new knowledge of the language they have learned, to enhance students' understanding of knowledge, to enhance the students' language application ability. When the main content of a new course is over, teachers should guide students to summarize knowledge in the process of learning a new language points, guide students to experience their understanding and awareness of the text contentin the process of learning, guide students to sum up the knowledge points learned in the new class through cooperation, to summarize the content of the focus and difficulty.In order to guide the students to analyze and study the learning skills and methods of learning in the course of learning, to summarize the learning methods and so on.Through the application of experiential learning method in the small knot, it is necessary to enable students to grasp some regularity and summarize the important knowledge points involved in the new course.Through the application of experiential learning method, students can truly feel their gains, feel success, and enhance their interest and confidence in English learning.Through this kind of education innovation, we can effectively expand the scope and depth of class contents, and promote the innovation and development of education activity in English picture book intensive reading course.

\section{References}

[1] Zhuo Sun, Yunxia Song. The strategy study of experiential learning applied to college English teaching [J]. Journal of Changchun education college. 2011 (01).

[2] Weigang Wang. Application on experiential learning in college English teaching [J]. Test weekly. 2010(14).

[3] Yuting Zou. The design and research onblended teaching in college English intensive reading courses [J]. Overseas English. 2017(10).

[4]Jingjing Meng. Study on the implementation model of college experiential English teaching [J]. College English (academic edition).2007 (01).

[5]Yanzi Ma.Experimental study on the influence of experiential English learning for English 
writing in junior middle school [D]. Shanxi university. 2011.

[6]Wenchao Li. Research on the feasibility of experiential learning in college English teaching [D]. Hebei university of science and technology. 2010. 